\title{
Islamisation of Engineering Education - A Case at IIUM
}

\author{
Abdullah Al Mamun ${ }^{1, *}$, Asan G. A. Muthalif ${ }^{2}$, Zuraida Ahmad ${ }^{1}$, Ahmad Faris Ismail ${ }^{1}$, Kamsiah Ismail ${ }^{1}$, \\ Md. Abdul Maleque ${ }^{1}$ \\ ${ }^{1}$ Faculty of Engineering, International Islamic University Malaysia (IIUM), Malaysia \\ ${ }^{2}$ Department of Mechanical and Industrial Engineering, Qatar University, Qatar
}

Received October 18, 2019; Revised December 24, 2019; Accetped December 30, 2019

Copyright $\bigcirc 2020$ by authors, all rights reserved. Authors agree that this article remains permanently open access under the terms of the Creative Commons Attribution License 4.0 International License

\begin{abstract}
Seeking knowledge and continuing education are very important elements in Islam. All Muslims (both male and female) are required to make sincere efforts to acquire knowledge for the benefits of themself and the society; They believe that there is only one God (Allah) and $\mathrm{He}$ is the ultimate source of all knowledge. Although the education system has various branches, this paper is intended to present the common issues related to the Islamic values and practices in engineering education and the ways to instil ethics \& spirituality into the technical education system. The step by step initiatives taken by the faculty of engineering at the International Islamic University Malaysia (IIUM) is highlighted in this paper. In order to achieve the goals of Islamisation of engineering education at IIUM, the relevant Islamic elements are added into the curriculums, textbooks are written and learning outcomes are set (at IIUM) to assess the student's ability in appreciating the link between the revealed and acquired knowledge. Generally, such initiatives are welcomed by the students, though it requires a substantial amount of continuous efforts from the academic staffs. It is realised that Islamisation of the engineering education and continuous reminder of spirituality in engineering practices are essential to reduce the corruption and unethical practices in the engineering profession, which is one of the major socio-economic problems in many countries, rich or poor, developed or developing. Steps taken in the engineering curriculum design is part of the faculty's initiatives to achieve its vision, which is to be a world-class centre for engineering education and research with values and ethics. Information shared in this paper could be beneficial for both secular and non-secular education system.
\end{abstract}

Keywords Corruption, Ethics, Islamisation, Spirituality, Revealed and Acquired Knowledge

\section{Introduction}

The education system is one of the dynamic elements of society. Not only mode and medium of teaching, learning, research, publication, etc. are changing, but the people's pursuit for education and its application is also changing the increasing complexity of the education domain. Although scientific and technical knowledge has advanced significantly compared to the past, engineering education has deviated, in many ways, from the ethical values and sense of spirituality (Reagan, 2005).

Since the first World Conference on Muslim Education in 1977, there have been many attempts to define the real purpose and target of knowledge and education in Islam (Sahin, 2018, Ishaq, 1989, Husain and Ashraf, 1979). Therefore, the concepts of Islamic education should be anchored to the strengths of faith (aqidah). It is prescribed that faith and knowledge should be integrated (Ahmed, 2014) to ensure that the individuals can be guided to become the khalifatullah (Allah's vicegerent). Knowledge and intellectual abilities of human should be closely linked to the One Creator (Allah). One of the main aims of education in Islam is to produce good Muslims with an understanding of Islamic rules strongly supported by faith (Jackson and Parker, 2008; Daud, 1998, Al-Faruqi, 1982).

Unfortunately, one of the main objectives of engineering education and research (both in secular and Muslim world) has turned commercial, instead of serving the humanity and protecting the environment. As such, Islamisation of technical knowledge and its application, specifically the engineering education of the modern days need to be blended with ethical and spiritual values for the Muslim Nations, perhaps including the others too. Such a move is necessary to reap benefits from the nature without making our future vulnerable. A few initiatives are already taken and being continued by various organisations for infusion of Islamic and other ethical values in the field of engineering, technical and other professional education systems (Osman, 2013; Hamzah et al., 2012; Zuraida et al., 2012; Golkar, 2012; Shuriye and Ismail, 2011).

Zuraida (2011) examined the prevailing engineering 
education system at the International Islamic University Malaysia (IIUM) and the integration of Islamic values in it. A framework for the Islamisation of engineering education was proposed, and the potential problems of the framework were discussed too. A few measures were suggested to surmount those obstacles and smooth progress towards success. Shuriye and Ismail (2011) gave an overview of the Islamisation of knowledge as a concept and directed it towards engineering and technology. They selected a few courses taught in the Faculty of Engineering and suggested several approaches to Islamise these courses. Later on, Zuraida (2012) discussed the problems faced in executing Islamisation of engineering education through a case study conducted at the IIUM. The author also highlighted the roles that can be played by Islamic educators to implement Islamisation in engineering education. Osman (2013) reported Islamisation of medical sciences and its teaching curriculum. He explained the experience of IIUM by describing how students are taught about medical knowledge and profession in the Islamic worldview.

Golkar (2012) analysed the efforts made to Islamise the universities of Iran after the Islamic revolution in 1979. He described that the efforts were made in two phases. However, his focus was basically on the events after 2005 when Ahmadinejad came into power. He also investigated the tactics and strategies adopted by the Iranians, including analysing the reasons for some failure events. Amin et al. (2011) outlined the effectiveness of Islamisation of education by presenting the case of IIUM. He investigated how Islamic values and courses integration is influencing on the IIUM graduates in their career. Al-Mighdadi (2011) discussed the issues of Islamisation of education, human being and knowledge. He concluded that there are differences among the Muslim scholars regarding Islamisation of knowledge and education system. However, he suggested a few recommendations to the education policymakers, Muslim scholars and practitioners to approach Islamisation. Hamzah et al. (2012) explained the conceptual model for the epistemology of knowledge in technical and engineering education. They put emphasis on understanding the purpose of engineering education and shifted the idea from a mere presentation of technical knowledge to the integration of knowledge.

Furlow (2005) described the Islamisation of knowledge of science, technology and medicine by examining four institutes in the USA and Malaysia. He performed a questionnaire survey and re-evaluated the relevance among Islam, Science and Modernity. It was commented that the Islamisation of knowledge is less rigidly definable. Therefore, individual participants are attracted either by the philosophical ideas or by a desire to affiliate with ideas and institutions where the educators or policymakers are attached to.

Hashim and Ssekamanya (2014) discussed the achievements, impediments and future of the Islamisation of IIUM. They mentioned the concept of Islamisation process of human knowledge and elaborately discussed the phases of Islamisation of knowledge (IOK) at IIUM. They also evaluated the IOK achievements of IIUM and mentioned the challenges. Suggestions were also given by them to accelerate the process. Obaidullah (2010) explained the concept of IOK and also gave details about the role of the universities to achieve this target. He illustrated his discussion with IIUM as a model. He also focused on how IIUM is contributing to this goal and suggested some measures. Ssekamanya et al. (2011) investigated the experiences of IOK of IIUM and discussed the challenges and successes. They interviewed 11 key personnel involved in the Islamisation process and management activities. They also cross-checked the interviewed information with course outlines taught at IIUM. They suggested more research works to be done to solve the problems of Muslim society, in particular, and of humanity in general.

The main objective of this paper is to share the progressive developments and achievements in the Islamisation of engineering education at the International Islamic University Malaysia (IIUM), which is considered to be a garden of knowledge and virtue and leading the Islamic way towards sustainable development of the society and humanity.

\section{Methodology}

This paper is written based on continued initiatives and efforts taken by the Faculty of engineering at IIUM. The course outlines are being continuously updated based on the feedback from students, industry, alumni, assessors, etc. The Islamisation of engineering education is being conducted by modifying course outlines and by enhancing teaching and learning techniques. Writing textbooks is also considered another important element necessary for the Islamisation process of engineering education and research. Other secondary information is also used in the preparation of this paper.

\subsection{Course Outlines}

The Faculty of Engineering at IIUM has integrated several Islamic courses (Table 1) into its curriculum towards Islamisation and also has shaped the courses to add Islamic values among the students and staffs. The courses are The Islamic Worldview (UNGS 2030); Islam, Knowledge and Civilisation (UNGS 2040); Ethics and Fiqh for Everyday Life (UNGS 2050); Engineering Ethics from Islamic Perspective (GENE 4300); Tilawah Al Quran I (TQ 1011) and Tilawah Al Quran II (TQ 2011). A brief outline of these courses is given in the following table to illustrate how Islamic values are integrated into the educational system. The courses are designed and are being improved to produce graduates who can have sound 
knowledge on the technological advancements and function in the society as "Rahmatan Lil "Alamin", which means "Blessings or Mercy to the Whole World" to ensure the sustainability of the whole eco-system and its creatures.

Tilawah Al Quran (TQ 1011) includes individual recitation of the Holy Quran, listening to the recitation of the instructor, guidance on the correct pronunciation of Quranic letters, emphasis on the correct pronunciation of Makhraj, Sifat, etc. to acquire the spiritual gain by reciting and realising the contents of Quran as accurately as possible. Tilawah Al Quran II (TQ 2011) includes Tarqeeq and Tafkheem in recitation, which is also intended for the gain of spiritual benefits; an element not much appreciated by the secular education system.

\subsection{Learning Outcomes}

Learning outcomes (LOs) are one of the important components in the engineering course outlines which are assessed by internal and external evaluators during the semesters. The LOs are set such that at the end of the completion of the courses, all the program outcomes (POs) are achieved. Instances of the LOs set for the Islamisation courses at the Faculty of Engineering, IIUM are given in Table 2 .

Table 1. Glimpse of Course Outlines being Used to Enhance the Ethics and Spiritualty in Engineering Education at IIUM

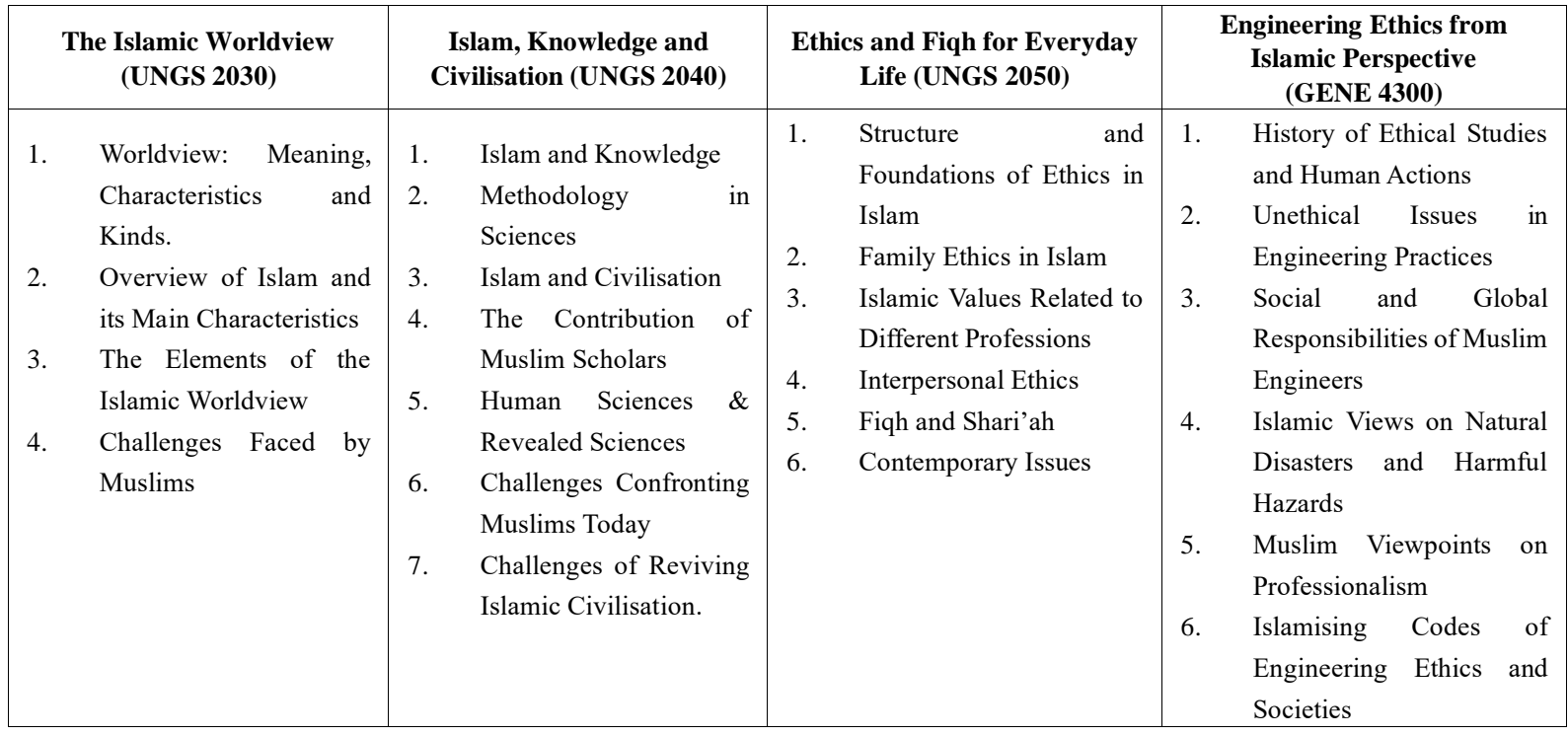

Table 2. Selected Learning Outcomes Assessed at the Faculty of Engineering at IIUM

\begin{tabular}{|c|c|c|c|}
\hline $\begin{array}{l}\text { The Islamic Worldview } \\
\text { (UNGS 2030) }\end{array}$ & $\begin{array}{l}\text { Islam, Knowledge and } \\
\text { Civilisation (UNGS 2040) }\end{array}$ & $\begin{array}{l}\text { Ethics and Fiqh for } \\
\text { Everyday Life } \\
\text { (UNGS 2050) } \\
\end{array}$ & $\begin{array}{c}\text { Engineering Ethics from Islamic } \\
\text { Perspective } \\
\text { (GENE 4300) } \\
\end{array}$ \\
\hline $\begin{array}{l}\text { 1. Demonstrate understanding } \\
\text { of the meanings, } \\
\text { characteristics and elements } \\
\text { of both Islamic and } \\
\text { non-Islamic worldviews. } \\
\text { 2. Explain the elements of } \\
\text { Islamic worldview and their } \\
\text { impact on individual and } \\
\text { social life. } \\
\text { Identify some of the } \\
\text { challenges faced by man and } \\
\text { society and suggest } \\
\text { solutions from the Islamic } \\
\text { worldview. }\end{array}$ & $\begin{array}{l}\text { 1. Show the impact of } \\
\text { Islamic civilisation } \\
\text { on other civilisations. } \\
\text { 2. Respond to the } \\
\text { contemporary } \\
\text { challenges facing } \\
\text { Muslims in the fields } \\
\text { of science and } \\
\text { technology. } \\
\text { Explain the possible } \\
\text { ways to revive } \\
\text { Muslim civilisation. }\end{array}$ & $\begin{array}{l}\text { Describe the } \\
\text { importance of Islamic } \\
\text { ethics and fiqh in } \\
\text { everyday life. } \\
\text { Respond to } \\
\text { contemporary moral } \\
\text { challenges from the } \\
\text { standpoint of Islam. } \\
\text { Demonstrate the } \\
\text { relationship between } \\
\text { ethics, fiqh, and law. }\end{array}$ & 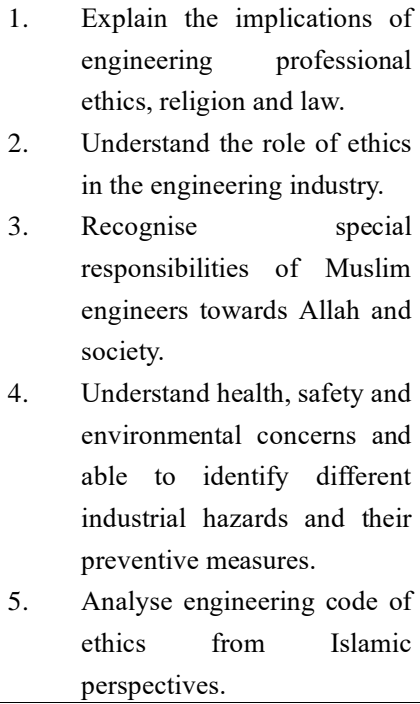 \\
\hline
\end{tabular}




\subsection{Textbooks}

Textbooks are one of the most challenging elements necessary to have Islamic components in the course contents. Therefore, several authors at IIUM have published and are making continuous efforts to publish more textbooks to achieve the objectives of Islamisation of engineering and other education. A few of the books used at the faculty of engineering are Riza \& Hussain (2015), Bakar (2014), Shuriye et al. (2009), Bakar (2006), As-Sibaa'ie (2003), Al-Qaradawi (2001), Al-Ghazali (1991), etc.

\section{Results and Discussion}

\subsection{Improvement of the Course Outlines}

Islamisation of the revised curriculum started with a more systematic approach which was by revising the Programme outcomes (POs). There are 12 POs set by the Faculty, and this is probably the only programme outcomes of engineering programme in Malaysia that explicitly mention the word 'Islamic'. The Faculty of Engineering's
PO \#8 states:

"Ethics (ESSE) - Apply professional ethics with Islamic values and commit to responsibilities and norms of professional engineering code of practices".

The engineering curriculum in Malaysia is monitored by the Engineering Accreditation Council (EAC), which is a member of the Washington Accord. In Outcome-based Education (OBE), the achievement of POs should be assessed to secure and continue accreditation. The EAC periodically assess and review the achievements of each engineering program as per the Manual (EAC, 2012; EAC, 2007; EAC, 2003). The inclusion of 'Islamic values' in PO means it is formally linked to the accreditation of the programme. Hence, assessing and achieving this $\mathrm{PO}$ is not an option but a necessity. A number of Faculty required courses and projects, which are common to all programmes, are also addressing to $\mathrm{PO} \# 8$. Specifically the subjects GEN 4300 on Engineering Ethics, Safety and Environment and MANU 1202 on Workshop Technology are compulsory for all programs to teach the students. In addition, the departments also have core courses mapped to $\mathrm{PO} \# 8$, as given in Table 3.

Table 3. Courses Mapped to Islamic Values for Each Programme

\begin{tabular}{|c|c|c|c|}
\hline No & $\begin{array}{l}\text { Engineering } \\
\text { Programme }\end{array}$ & Courses Mapped to PO \#8 & Courses Common to All Programme \\
\hline & Manufacturing & $\begin{array}{l}\text { ECON } 1550 \text { Introductory Economics for } \\
\text { Engineers } \\
\text { MECH 3300 Integrated Design Project }\end{array}$ & \multirow{9}{*}{$\begin{array}{l}\text { Core and Common Courses } \\
\text { - Seminar } \\
\text { - Workshop Technology } \\
\text { - Integrated Design } \\
\text { - Engineering Industrial Training } \\
\text { - Final Year Project I } \\
\text { - Final Year Project II } \\
\text { Faculty Courses } \\
\text { MANU } 3318 \text { Engineering Economics and } \\
\text { Management } \\
\text { MANU } 4211 \text { Technology Entrepreneurship } \\
\text { University Required Courses } \\
\text { UNGS } 2030 \text { The Islamic Worldview } \\
\text { UNGS } 2040 \text { Islam, Knowledge and Civilisation } \\
\text { UNGS } 2050 \text { Ethics and Fiqh for Everyday Life } \\
\text { GENE } 4300 \text { Engineering Ethics from Islamic } \\
\text { Perspective } \\
\text { TQ 1011 Tilawah I } \\
\text { TQ } 2011 \text { Tilawah II } \\
\text { Co-Curricular } \\
\text { CCHB } 1011 \text { Study Circle I } \\
\text { CCHB } 1012 \text { Study Circle II } \\
\text { CCLM } 2051 \text { Leadership and Management } \\
\text { CCFM } 2052 \text { Family Management \& Parenting }\end{array}$} \\
\hline & Materials & $\begin{array}{l}\text { MATR } 3312 \text { Polymers } \\
\text { MATR } 4351 \text { Electronic Packaging }\end{array}$ & \\
\hline & Automotive & $\begin{array}{lll}\text { ECON } 1550 \quad \text { Introductory } \text { Economics for } \\
\text { Engineers } \\
\text { EITR 3512 Engineering Industrial Training. }\end{array}$ & \\
\hline & Aerospace & $\begin{array}{l}\text { MEC } 3825 \text { Control Systems } \\
\text { ECON } 1550 \text { Introductory Economics for } \\
\text { Engineers }\end{array}$ & \\
\hline & Mechatronics & $\begin{array}{l}\text { MCTE } 4314 \text { Digital Signal Processing } \\
\text { EITR } 3561 \text { Engineering Industrial Training. }\end{array}$ & \\
\hline & Communication & $\begin{array}{l}\text { ECOM } 3101 \text { Communication Engineering Lab I } \\
\text { ECOM } 3300 \text { Integrated Design Project }\end{array}$ & \\
\hline & $\begin{array}{l}\text { Computer and } \\
\text { Information }\end{array}$ & $\begin{array}{l}\text { ECIE } 4311 \text { Software Engineering Design } \\
\text { ECIE } 4312 \text { Multimedia Information Systems }\end{array}$ & \\
\hline & Civil & $\begin{array}{l}\text { CIVE } 3321 \text { Construction Engineering } \\
\text { CIVE } 4213 \text { Contract and Construction } \\
\text { Management } \\
\text { CIVE 3325 Environmental Engineering }\end{array}$ & \\
\hline & $\begin{array}{l}\text { Biotechnology- } \\
\text { Biochemical }\end{array}$ & $\begin{array}{l}\text { BTEN } 3433 \text { Molecular Biology and Genetic Eng. } \\
\text { BTEN } 4222 \text { Bioprocess Facility Design } \\
\text { BTEN } 4223 \text { Eng. Aspect of Animal and Plant Cell } \\
\text { Culture } \\
\text { BTEN } 4232 \text { Molecular Farming } \\
\text { BTEN } 3316 \text { Introduction to Environmental } \\
\text { Engineering }\end{array}$ & \\
\hline
\end{tabular}


Introduction of Islamic related final year project (FYP) and integrated design project (IDP) titles are made compulsory for departments to offer related titles every semester. A few of the completed projects are prayer-mat for senior citizens, Qiblah identification for blinds, prosthetic limbs for prayers. When discussing on Islamisation in the field of science and engineering, it is believed that the source of knowledge is from the Almighty Allah (the Only Creator God) which is notably only part related to Aqidah (creed or faith), while the remaining comes in Akhlaq (the practice of morality and good manners). The teaching of engineering practices in accordance to Islam is an important aspect of Islamisation at the Kulliyyah (Faculty) of Engineering. For example, design, fabrication and its application are the common steps in engineering processes. Each of these steps is being taught in accordance with the professional ethics blended with Islamic values. This is reminded to the engineering students repeatedly to know their responsibilities as a vicegerent of Allah.

i. Design: Students are taught to consider issues such as public health and safety, cultural, societal, economical, ethical, environmental, sustainability issues, societal, global, and environmental contexts to benefit the modelling of Ummah and humanity.

ii. Fabrication: Source of materials, selection of components and fabrication process itself to be in accordance with Islamic values and permissibility.

iii. Application: Although the source of knowledge is the Almighty Allah (the Only God), the application or implementation of knowledge is often misused by a human. Engineering is one of the most important fields in which misuse and unethical exercise of the knowledge, authority and power may bring harm to humanity and society.

The culture of continuous life-long learning is being practiced through the profession. More training and seminars are being given to staff members on Islamic aspects in engineering education and practices.

\subsection{Assessment of LOs and POs}

An assessment done by Zuraida et al. (2012) based on their own experience and observation through their teaching career at IIUM gives the following information regarding those learning and program outcomes with Islamic value.

1. Memorization of some hadith relating, the sincerity of intention, Man as khalifatullah, the significance of 'ilm the need for brotherhood among Muslims.

2. Contribution of Muslim scholars in the respective field.

3. The realisation of Islam as part and parcel of their life as well as the engineering education system.

\subsection{Lecturers' Responses}

In reality, the majority of the staffs appreciate such initiatives while only very few occasionally express redundancy citing that anything good for the humanity is Islamic. There is no need to explicitly mention the Islamisation of course contents or setting learning outcomes.

\subsection{Students' Feedback}

A survey performed by Zuraida et al. (2014) on the engineering students reveals the following information regarding their own opinion.

1. The class should be in motion to entertain students through which they will learn.

2. Exam-oriented classes should not be imposed, which diverts the intention of seeking knowledge from Ibadah to achieving good grades.

3. The need for a particular subject in their future career should be explained explicitly.

4. Updated materials should be included in the curriculum.

\subsection{Alumni Responses}

The courses which are mentioned and related to Islam are compulsory for every undergraduate student. However, a recent survey done by the Ministry of Higher Education (MOHE) Malaysia through online questionnaire revealed information that more than $97 \%$ of the students commented that they are satisfied with these courses (Amin et al., 2011). The same survey also stated that $67.3 \%$ of the IIUM graduates were employed within six months of their degree completion, which is higher than the national average of 63.3\% (Amin et al., 2011). This information reveals that Islamisation of the educational system has a positive impact on the students and the job market, which is also reflected by the alumni of IIUM.

\section{Concluding Remarks}

Realising the demands, complexities and challenges of the ever-evolving modern societies, the faculty of engineering at IIUM has taken serious steps in the Islamisation of the engineering curriculum. This is in line with its vision "to be a world-class centre of engineering education and research with values and ethics", and its mission "to be the reference hub for engineering education and innovative solutions based on Islamic traditions to serve humanity". Rigorous steps are taken to embrace Islamic teaching, ethics and values in the engineering curriculum at IIUM. Imparting engineering knowledge with Islamic values and practices requires trained staff members. In line with the mission and vision of IIUM, which is to lead the way to be a "Garden of knowledge and virtue", the faculty of engineering is also making continuous efforts to produce more Islamic processes and 
products necessary for the big global halal market. Awareness of staff members on Islamic aspects in engineering practices is one of the key components in Islamisation of engineering education and research. The faculty has taken various initiatives to provide more training and seminars for academic and supporting staff members in making the effort a success. The academic staff of all levels at IIUM are recommended to write textbooks to align the engineering and technical components with Islamic values and ethics. As technological advancement is happening very fast, it is strongly recommended that dissemination of knowledge should be blended with various levels of spirituality combined with balanced amount of moral, ethical and religious teachings. Such that value of the society, humanity and the surrounding ecosystem is not left behind or neglected.

\section{Acknowledgements}

The authors gratefully acknowledge all supports provided by the IIUM, including other organisations' and individuals' assistance in preparing the paper. Special gratitude is expressed to the current (2019) deputy dean (academic affairs) of the faculty of engineering, Dr. Sany Izan Ihsan, for providing information related to the updates in the curriculum review at the faculty.

\section{REFERENCES}

[1] Ahmed, M.K. (2014). Perspectives on the Discourse of Islamization of Education. American Journal of Humanities and Social Sciences, 2(1), 43-53.

[2] Al-Mighdadi, M.H. (2011). Issues in Islamisation of Knowledge, Man and Education. Revue Académique des sciences humaines et sociales, 3-16.

[3] Al-Ghazali, M. (1991). Muslim Behaviour. Kitab Bhaban, New Delhi, India.

[4] Al-Faruqi, I. (1982). Islamisation of knowledge, Herndon, VA IIIT.

[5] Al-Qaradawi, Y. (2001). The Lawful and the Prohibited in Islam. Islamic Book Trust, Kuala Lumpur, Malaysia.

[6] As-Sibaa'ie (2003). The Life of Prophet Muhammad Highlights and Lessons. International Islamic Publishing House. Riyadh, Saudi Arabia.

[7] Amin, R.M., Yusof, S.A. \& Haneef, M.A. (2011). The Effectiveness of an Integrated Curriculum: The Case of the International Islamic University Malaysia. Center for Islamic Economics and Finance, Qatar Faculty of Islamic Studies.

[8] Bakar, O. (2014). Islamic Civilisation and the Modern World: Thematic Essays. UBD Press, Brunei Darussalam.

[9] Bakar, O. (2006). Classification of Knowledge in Islam.
International Institute of Islamic Thought and Civilisation (ISTAC). Kuala Lumpur, Malaysia.

[10] EAC (2003). Engineering Accreditation Council Manual 2003, Engineering Accreditation Malaysia, Board of Engineers Malaysia.

[11] EAC (2007). Engineering Programme Accreditation Manual 2007, Engineering Accreditation Malaysia, Board of Engineers Malaysia.

[12] EAC (2012). Engineering Programme Accreditation Manual 2012, Engineering Accreditation Malaysia, Board of Engineers Malaysia.

[13] Furlow, C.A. (2005). Islam, science, and modernity: from Northern Virginia to Kuala Lumpur. Doctoral dissertation, University of Florida.

[14] Golkar, S. (2012). Cultural Engineering under Authoritarian Regimes: Islamisation of Universities in Post-revolutionary Iran. Digest of Middle East Studies, 21(1), 1-23.

[15] Hamzah, R., Ismail, S. \& Isa, K.M. (2012). Conceptual Model for Epistemology of Knowledge in Technical and Engineering Education.

[16] Hashim, R. \& Ssekamanya, S.A. (2014). Islamisation of Human Knowledge in Theory and Practice: Achievements, Challenges and Prospects in the IIUM context. IIUM Journal of Educational Studies, 1(1\&2).

[17] Husain, S.S. \& Ashraf, S.A. (1979). Crisis in Muslim education. Jeddah, Saudi Arabia: Hodder and Stoughton.

[18] Ishaq, F. (1989). Islamisation of the Discipline of Education, The American journal of Islamic Social Sciences, Vol. 6, No. 2, 307.

[19] Jackson, E. \& Parker, L. (2008). Enriched with knowledge': Modernisation, Islamisation and the Future of Islamic Education in Indonesia. Review of Indonesian and Malaysian Affairs, 42(1), 21-53.

[20] Obaidullah, M. (2010). The Role of Universities towards Islamisation of Knowledge: The IIUM as A Model.

[21] Osman, A. (2013). Integrating Islamic Value in Medical Teaching Curriculum: IIUM Experience. Bangladesh Journal of Medical Science, 12(2), 117-120.

[22] Reagan, T. (2005). Non Western Educational Traditions: Indigenous Approaches to the Educational Thought and Practice, (3rd Ed.) Mahwah, NJ: Lawrence Erlbaum Associates, Publisher.

[23] Riza M. \& Hussain D. (2015). Islam: The Way of Revival. Kobe Publishing Limited.

[24] Sahin, A. (2018). Critical Issues in Islamic Education Studies: Rethinking Islamic and Western Liberal Secular Values of Education. Religions, 9(335), 1-29.

[25] Shuriye, A.O. \& Ismail, A.F. (2011). Qur'anic values and engineering studies: approaches and methods in the process of Islamising engineering curriculum.

[26] Shuriye, A.O., Ismail, A.F. \& Dahalan, A.G. (2009). Ethics of Engineering Education. IIUM Press, Gombak, Malaysia.

[27] Ssekamanya, S.A., Hussein, S., \& Ismail, N.A.H. (2011). The experience of Islamisation of Knowledge at the 
International Islamic University Malaysia: successes and challenges.

[28] Wan Daud, W.M.N (1998). The Educational Philosophy and Practice of Syed Muhammad Naquib al-Attas: An Exposition of the Original Concept of Islamisation, International institute of Islamic Thought and Civilisation (ISTAC), Kuala Lumpur, Malaysia.

[29] Zuraida, A. (2011). Islamisation of Engineering Education in International Islamic University Malaysia (IIUM): Problems and Prospect. Revelation and Science, 1(03).

[30] Zuraida, A., Raihan, O. \& Ismail, A.F. (2012). Integrating and infusing of Islamic values in the existing engineering course subject: a case study. Advances in Natural and Applied Sciences, 6(5), 625-632.

[31] Zuraida, A., Zahurin H., Souad M.A., Salleh, M.N. \& Ismail, A.F. (2014). Tapping into student's passion, curiosity, engagement and dreams: engineering educator's task. Sci. Int. 26(5), 2563-2569. 